ing of the specific context of the region. It is not enough just to transplant Western curricula, they should be transformed to work in a specific setting.

\section{Faculty Updating and Training}

The decline in funding for higher education has also affected the economic position of the faculty. University professors who have spent their careers transmitting what is already known, are not equipped to create new, advancedlevel knowledge. For instance, those who formerly taught "scientific communism" may now be teaching "political science." However, they retain traditional methods and programs. It is mostly the senior academic staff (doctoral candidates or degree holders) who are in need of an updating of their disciplinary knowledge and expertise.

However, today a reevaluation of these disciplines is under way. Universities are attempting to reorganize academic faculties by recruiting experts whose ideas are consistent with the reforms (i.e., persons with advanced training in Western universities) or by recruiting staff (from lab assistants to the highest rank of professors) on a competitive basis. The Ministry of Education and Science has also recently developed a distance-learning program to fill the gaps in expert training. Language training, especially in English, is required to enable faculty to communicate with colleagues in their field outside Armenia.

Many universities and institutes now realize that training new and old academic staff for the new curriculum will require a long-term commitment. Still, the existing environment complicates the task of faculty training. Some pro- fessors feel on the defensive and unsure about the validity of the changes. Others, especially senior faculty, are still opposed to change. Moreover, the fact that the faculty are often forced to find outside work to supplement their salaries decreases the amount of time they can spend on teaching and research. Besides, only teaching has been broadly funded, while research funding is in very short supply. Even when a proposal is approved, after peer review, by the $\mathrm{Na}$ tional Academy of Sciences of Armenia and the Ministry of Education and Science, it often dies for lack of funding. This situation has resulted in a brain drain problem for the country's education system.

\section{An Action Plan}

Finally, to bring the universities and their faculties into line with higher education in the West, an 8-to-10-year action plan is being developed, based on the achievements and lessons of the transition period. The plan includes the following goals: 1) improve communications among universities in order to provide better coordination; 2) stimulate the formation of a dynamic system of higher education to encourage improvement of quality and expanding the range of programs offered; 3 ) raise the profile and value of accreditation of programs and institutions of higher education; and 4) foster and introduce innovative institutional structures and make the most effective use of new technology.

Author's note: This article was supported in part by the Bureau of Educational and Cultural Affairs of the U.S. State Department. The opinions expressed here are the author's own.

\title{
Bridging the Gap between Higher and Secondary Education in Russia
}

\section{Anna Smolentseva}

Anna Smolentseva is on the staff of the Center for Sociological Studies, Moscow State Lomonosov University. Address: 11 Mokhovaya Ul., Moscow, Russia 103009. Tel.: (095) 203-60-74; Fax: (095) 203-6334; E-mail: <anna@opinio.msu.ru>.

$\mathrm{T}$ he successful functioning of the educational system as a social institution requires maintaining continuity and consistency between different levels, especially secondary and higher education. This poses a challenge for educators and policymakers seeking to ensure sustainable development of a national system of education. In Russia, the interaction between secondary and higher education has become a serious problem that must be resolved in the near future.

\section{Rising Demand}

Traditionally, Russian higher education was designed to prepare highly qualified professionals or specialists. Admission to public universities, which comprise about two-thirds of all Russian universities, is based on applicants' perfor- mance on entrance examinations. In the last five years, the demand for higher education has grown to historic levels: in 1999, there were 246 students per 10,000 population. Nevertheless, the proportion of the population in Russia that participates in higher education (2.4 percent) is much smaller than that in most developed countries. University entrance examinations have become much more competitive. In 1999, there were more than 200 applicants for every 100 places in public universities. In the most prestigious universities, the number of applicants can amount to as many as 12 to 14 for each place.

\section{Admissions Requirements}

A major problem is the significant gap between highly demanding university entrance examinations and the insufficient levels of knowledge that school graduates possess. This gap means that secondary school graduates need additional preparation to gain admission to higher educational institutions. According to some estimates, no more than onethird of students enter university while relying solely on 
the knowledge acquired in school. Another one-third take special preparatory courses; approximately one-fifth hire private tutors, and as many educate themselves.

The burden of extra work and expenses weighs heavily on secondary school students and their families. Private classes to prepare for entrance examinations cost between U.S.\$10 and $\$ 40$ an hour. Given the current economic crisis and the low standard of living of most Russians, many young people find it difficult to gain admission to institutions of higher education. Also, the system creates abundant possibilities for corruption (bribes, favors for the well-connected, etc.).

\section{Traditionally, Russian higher education was designed to prepare highly quali- fied professionals or specialists.}

The other side of this problem is that the "quality" of incoming students, in the opinion of many faculty members, is diminishing from year to year across the country. The level of students' general knowledge and skills is quite low. They are unable to work independently and lack initiative. It can be said that students need the additional courses and tutoring, not just to pass the entrance examinations but also to prepare them for their university studies. The new regulations that prescribe strict correspondence between courses taught in secondary schools and university admission requirements have not yet raised academic standards.

Filling the gap between secondary and higher education and finding a balance between educational levels are very important issues in Russia. The dilemma is deciding how to address these issues: should we lift secondary education up to the level of higher education or should we lower the standards of admission down to current standards at the secondary level?

Meanwhile, demographic trends in Russia have moved the debate over these problems to another arena. Stiff competition for admission to universities is expected to last until 2004, when the number of secondary school graduates will begin to decrease. By 2009 entrance examinations will be meaningless because the number of secondary school graduates will be less than the number of available places in public universities (1.3 million school graduates and 1.7 million places in higher educational and secondary professional institutions). Moreover, this situation will occur in some regions (including the major cities of Moscow and Petersburg) in just four years. The reason is a demographic decline in the age cohort. All this is throwing out new challenges for Russian education and society. Which should have priority: providing advanced professional and voca- tional education for everyone or maintaining the competition for the spaces in the university? Also, the absence of competition for admission to public universities would lead to a decline in the number of students at private universities. Only the most successful private institutions would survive (there are now 251,000 students in private universities and 3,347,000 in public ones).

An active search recently ended for strategies to resolve this and other problems in Russia. In January 2000, a new "national doctrine of education in the Russian Federation" was discussed at the All-Russia meeting of educators. The doctrine, which was developed over a two-year period, defines the issues of high priority in Russian education-namely, financing and future development. It was recently passed into law by Parliament and guarantees tuition-free professional and higher education for 50 percent of the students (those who pass a competitive examination) and tuition-free graduate education for those who pass another examination. Those who do not score well enough on the examinations will pay tuition.

To fill the gap between secondary and higher education, there is a need to change existing admission procedures in higher education institutions. One option under discussion is admissions based on secondary school graduation certificates. This system is followed in France and Germany. However, in Russia such a system would seem to be unrealizable as yet due to major descrepancies between standards of secondary education in urban and village areas. Village areas account for about 70 percent of all schools, and the quality of education there is quite poor. Another option is introducing a system of centralized national testing (as in the United States), which also has its own pros and cons.

\section{Stiff competition for admission to uni- versities is expected to last until 2004, when the number of secondary school graduates will begin to decrease.}

Bridging the gap between secondary and higher education also requires greater continuity and consistency in the curricula of secondary and higher education; establishing multilayer educational institutions that include both secondary and higher educational institutions; negotiating contracts between schools and universities about cooperation; and upgrading teachers' qualifications, among other things. Finally, a gradual transition to a 12-year school system will reduce the excessive workload on secondary school students and enhance preparation for the university by improving the quality of education. 